\title{
Changes in $\alpha_{2}$-adrenoceptor number and function in brains of morphine-dependent rats
}

\author{
Charles B. Smith ${ }^{1, *}$, Hylan C. Moises ${ }^{2}$, Robert N. Spengler ${ }^{1}$ and Peggie J. Hollingsworth ${ }^{1}$ \\ Departments of ' Pharmacology and ' ${ }^{2}$ hysiology, The University of Michigan Medical School, Ann Arbor, MI 48109, U.S.A.
}

Received 1 September 1988, revised MS received 24 November 1988, accepted 6 December 1988

The effects of long-term treatment of rats with morphine sulfate were assessed upon the specific binding of $\left[{ }^{3} \mathrm{H}\right]$ clonidine to $\alpha_{2}$-adrenoceptors on neural membranes isolated from various brain areas and upon the function of presynaptic $\alpha_{2}$-adrenoceptors during field stimulation of hippocampal slices. Rats were injected with morphine every 8 $\mathrm{h}$ for 14 days with doses which started at $10 \mathrm{mg} / \mathrm{kg}$ per injection i.p., and which increased every 3 days to a final dose of $100 \mathrm{mg} / \mathrm{kg}$ per injection on the last 2 days. At 8 and $32 \mathrm{~h}$ after the last injection the $B_{\max }$ for $\left[{ }^{3} \mathrm{H}\right]$ clonidine binding to neural membranes from various brain areas was significantly decreased. At the same times, the fractional release of $\left[{ }^{3} \mathbf{H}\right]$ noradrenaline during field stimulation of hippocampal slices was increased and the sensitivity of the hippocampal slice to clonidine was reduced which indicated the development of a functional subsensitivity of the presynaptic $\alpha_{2}$-adrenoceptor. These changes in receptor function persisted at $72 \mathrm{~h}$ after the last morphine injection although at this time there were marked increases over control values in $\left[{ }^{3} \mathrm{H}\right]$ clonidine binding to membranes from all rat brain areas except the caudate nucleus. These findings suggest that changes in $\alpha_{2}$-adrenoceptor number and function which develop during long-term morphine administration might play an important role in opiate dependence.

$\alpha_{2}$-Adrenoceptors; Morphine dependence; Morphine withdrawal; Hippocampal slices; $\left[{ }^{3} \mathrm{H}\right]$ Clonidine binding; Brain; (Field stimulation, Rat)

\section{Introduction}

Morphine and related narcotic analgesics have long been known to modify noradrenergic nerve function in the rodent brain. Acute administration of morphine increased the turnover of dopamine (Clouet and Ratner, 1970) in the rat brain and noradrenaline and dopamine in the mouse brain (Smith et al., 1970; 1972). When mice were made dependent upon morphine, tolerance developed to these effects. After withdrawal of morphine from dependent mice, decreases in the turnover of

\footnotetext{
* To whom all correspondence should be addressed: Department of Pharmacology, 0626, M6428 Medical Science I, The University of Michigan Medical School, Ann Arbor, MI 48109, U.S.A.
}

catecholamines occurred which followed the time course of the abstinence syndrome (Rosenman and Smith, 1972). The reasons for these changes in catecholamine turnover have never been elucidated.

Presynaptic receptors play an important role in the regulation of noradrenaline release from neurons. A major mechanism which controls the release of noradrenaline appears to be the feedback inhibition of release by noradrenaline located in the synaptic cleft. This inhibition is mediated by stimulation of the presynaptic $\alpha_{2}$-adrenoceptor (Langer, 1981; Starke, 1981). In recent years radioligand binding techniques have been used to study $\alpha_{2}$-adrenoceptors in the rat brain (for reviews see Bylund and U'Prichard, 1983; U'Prichard, 1984). A number of investigators have 
attempted to assess the status of $\alpha_{2}$-adrenoceptors in the rat brain after acute and chronic morphine treatment by measuring the specific binding of $\left[{ }^{3} \mathrm{H}\right]$ clonidine to neural membranes isolated from various areas of the brain (Hamburg and Tallman, 1981; Sethy and Harris, 1982; Smith et al., 1983; Vicentini et al., 1983). One study also assessed binding of $\left[{ }^{3} \mathrm{H}\right]$ clonidine to rat brain membranes during the morphine abstinence syndrome (Ulibarri et al., 1987). The results of such investigations have been somewhat equivocal, and none of these studies attempted to relate changes in $\alpha_{2}$-adrenoceptor density to changes in $\alpha_{2}$-adrenoceptor function.

A preliminary study has suggested that changes in $\alpha_{2}$-adrenoceptor function occur in hippocampal slices from rats made dependent upon morphine (Moises et al., 1986). The purpose of the present study was to correlate changes in receptor number and/or affinity with changes in receptor function in rats treated for 1 or 14 days with increasing doses of morphine sulfate. To determine the density of $\alpha_{2}$-adrenoceptors the specific binding of $\left[{ }^{3} \mathrm{H}\right]$ clonidine to neural membranes from various brain areas was measured. To assess presynaptic $\alpha_{2}$-adrenoceptor function, the release of $\left[{ }^{3} \mathrm{H}\right]$ noradrenaline from hippocampal slices during field stimulation was measured at various frequencies of stimulation and in the presence of clonidine, an $\alpha_{2}$-adrenoceptor agonist. This study shows that with long-term administration of morphine both the number of $\alpha_{2}$-adrenoceptors and the sensitivity of the presynaptic $\alpha_{2}$-adrenoceptor to clonidine decreases. Seventy-two hours after withdrawal of dependent rats from morphine, and at a time when the abstinence syndrome is no longer present, a marked increase in specific binding of $\left[{ }^{3} \mathrm{H}\right]$ clonidine occurs in many brain areas which is not accompanied by an increase in sensitivity of the hippocampal slice preparation to clonidine.

\section{Materials and methods}

\subsection{Animals and treatment schedule}

Male, Sprague-Dawley rats, weighing 180-220 g at the start of the study, were used. Animals were housed in groups of six and allowed free access to food and water. Rats were injected with saline or morphine sulfate i.p. every $8 \mathrm{~h}$ for 14 days. The dose of morphine started with $10 \mathrm{mg} / \mathrm{kg}, 3$ times a day (t.i.d.) on the first day, was doubled every third day, and was maintained at $100 \mathrm{mg} / \mathrm{kg}$ t.i.d. on the last two days of the schedule. Control animals were given i.p. injections of saline according to the same treatment schedule.

\subsection{Measurement of specific binding of $\left[{ }^{3} \mathrm{H}\right]$ cloni- dine to neural membranes in rat brain homogenates}

Groups of six rats were used. At various intervals of time after the last injection of morphine or saline, the rats were killed by decapitation, their brains removed rapidly and placed in ice-cold Krebs physiological buffer solution and subsequently dissected according to a modification of the method described by Glowinski and Iversen (1966). The Krebs buffer consisted of ( $\mathrm{mM}$ ): $\mathrm{NaCl}$ 118; $\mathrm{KCl} 4.8 ; \mathrm{CaCl}_{2}$ 1.3; $\mathrm{KH}_{2} \mathrm{PO}_{4} 1.2 ; \mathrm{MgSO}_{4}$ 1.2; $\mathrm{NaHCO}_{3}$ 25; disodium EDTA 0.03; glucose 10; ascorbic acid 0.06. The following regions were studied: hippocampus, amygdala, hypothalamus, parietal-occipital cortex, caudate nucleus, and an area of the brainstem which contained the locus coeruleus.

The specific binding of $\left[{ }^{3} \mathrm{H}\right]$ clonidine to $\alpha_{2}-$ adrenoceptors in homogenates was measured as follows. Tissues pooled from the six rats were homogenized in $5 \mathrm{ml}$ of ice-cold Tris-sucrose buffer (Tris-HCl $5 \mathrm{mM}$; sucrose $250 \mathrm{mM} ; \mathrm{MgCl}_{2} 1 \mathrm{mM}$; $\mathrm{pH}$ 7.4). The homogenates were centrifuged at $1100 \times g$ for $10 \mathrm{~min}$, and the supernatants were saved. The supernatants were next centrifuged at $40000 \times g$ for $10 \mathrm{~min}$, and the pellet saved. The pellet was washed twice with $2 \mathrm{ml}$ of fresh incubation buffer (Tris- $\mathrm{HCl} 40 \mathrm{mM} ; \mathrm{MgCl}_{2} 10 \mathrm{mM} ; \mathrm{pH}$ 7.5) and recentrifuged at $40000 \times g$ for $10 \mathrm{~min}$. The final pellet was resuspended in an appropriate volume of Tris-incubation buffer. In equilibrium studies total $\left[{ }^{3} \mathrm{H}\right]$ clonidine binding was measured in $1 \mathrm{ml}$ aliquots of the fresh membranes which were incubated in duplicate for $30 \mathrm{~min}$ at $25^{\circ} \mathrm{C}$ with 0.5-64 $\mathrm{nM}\left[{ }^{3} \mathrm{H}\right]$ clonidine (specific activity 32-45 $\mathrm{mCi} / \mathrm{mmol}$, N.E.N., Boston, MA). Nonspecific binding was determined by adding un- 
labelled clonidine hydrochloride, $10 \mu \mathrm{M}$ (Boehringer, Mannheim, W. Germany), as well as the radioligand to a second pair of incubates. Specific binding was defined as the difference between total and non-specific binding. In drug competition studies, the neural membranes were incubated with $\left[{ }^{3} \mathrm{H}\right]$ clonidine at a concentration of 4 $\mathrm{nM}$ in the presence of concentrations of morphine up to and including $100 \mu \mathrm{M}$. Incubations were terminated by rapid filtration under vacuum through Whatman GF/C glass fiber filters and by washing with two $10 \mathrm{ml}$ aliquots of Tris-incubation buffer $\left(25^{\circ} \mathrm{C}\right)$. After termination of the incubation, the glass fiber filters were air dried and then placed in glass scintillation vials and counted for radioactivity as described by Smith et al. (1972). A computerized program (EBDA, McPherson, 1983) was used to develop preliminary estimates of the apparent dissociation constants $\left(K_{D}\right)$ and the maximum number of binding sites $\left(B_{\max }\right)$ for the $\left[{ }^{3} \mathrm{H}\right]$ clonidine. The values obtained from this program were used as the preliminary estimates required for the non-linear regression analysis program devised by Munson and Rodbard (1980) which was used to develop the final values for $\mathrm{K}_{\mathrm{D}}$ and $\mathrm{B}_{\max }$. Protein determinations were performed by the method of Lowry et al. (1951) in which bovine serum albumin was used as the protein standard.

\subsection{Field stimulated brain slices}

Rat brains were removed as described above. The hippocampi were isolated, and two transverse sections, $0.5 \mathrm{~mm}$ thick, were made perpendicular to the longitudinal axis of each hippocampus. The slices included the regio superior and the regio inferior of the dorsal hippocampus, the dentate gyrus and a portion of the subiculum. The four slices were equilibrated for $10 \mathrm{~min}$ in Krebs buffer saturated with $95 \% \mathrm{O}_{2}-5 \% \mathrm{CO}_{2}$ at $37^{\circ} \mathrm{C}$. After the period of equilibration, the slices were incubated with $\left[{ }^{3} \mathrm{H}\right.$ ]noradrenaline, $300 \mathrm{nM}$, for an additional 15 min, washed twice with fresh Krebs buffer and transferred to $0.25 \mathrm{ml}$ superfusion chambers. Each slice was lodged between two nylon mesh disks which in turn were sandwiched between two concentrically coiled platinum electrodes. Each slice was superfused at a rate of $0.5 \mathrm{ml}$ per min for a 30 min equilibration period prior to the onset of field stimulation.

Field stimulation consisted of trains of squarewave pulses (100 mA, $2 \mathrm{~ms}$ duration) at either 1 or $4 \mathrm{~Hz}$ for $2 \mathrm{~min}$ periods. The first period of stimulation occurred immediately after the initial 30 min superfusion period, and stimuli were applied at a frequency of $1 \mathrm{~Hz}$. The second and all subsequent periods of stimulation occurred at $16 \mathrm{~min}$ intervals during which stimuli were applied at a frequency of $4 \mathrm{~Hz}$. There were nine stimulation periods in each experiment. The release of $\left[{ }^{3} \mathrm{H}\right]$ noradrenaline during the second stimulation period represented the baseline response. Two of each set of four slices were stimulated but did not receive any drug. For the other two slices drugs were introduced into the superfusion buffer immediately after the second and each subsequent period of stimulation. Drug concentrations were increased by approximately 3-fold increments in order to construct a complete concentration-effect curve. When one accounts for the time that it took for the drug to reach the superfusion chamber, each slice was equilibrated in the presence of each drug concentration for a period of $13.5 \mathrm{~min}$ after which the slice was stimulated for an additional 2 $\min$.

Aliquots of the superfusate $(2 \mathrm{ml})$ were collected at $4 \mathrm{~min}$ intervals with a LKB fraction collector and then transferred to glass scintillation vials. Immediately after the last aliquot of superfusate was collected, the tissue slice was removed from the superfusion chamber, blotted, weighed, and homogenized in $0.05 \mathrm{ml}$ NCS tissue solubilizer. Bray solution $(15 \mathrm{ml})$ was added to each aliquot of superfusate and to the solubilized tissue, and the samples were counted as described above. Release of $\left[{ }^{3} \mathrm{H}\right]$ noradrenaline is expressed as the amount of labelled amine in each aliquot given as a percentage of the amount of labelled amine in the tissue immediately before collection of that aliquot. The stimulation-evoked release was calculated as the difference between the total release during the period of stimulation less the estimated basal release. Complete dose-response relationships were determined for clonidine, an $\alpha_{2}$-adrenoceptor agonist, with these preparations 
in order to detect alterations in the sensitivity of presynaptic $\alpha_{2}$-adrenoceptors. $\mathrm{EC}_{50} \mathrm{~s}$ were computed by the method of probit analysis described by Goldstein (1964). All results are expressed as mean values \pm S.E.M. Statistical significance was evaluated with Student's t-test.

\section{Results}

\subsection{Binding of $\left[{ }^{3} \mathrm{H}\right]$ clonidine to neural membranes}

High affinity binding to neural membranes was rapid, saturable and reversible by clonidine, $10^{-5}$ $M$. The regional distribution of specific binding in
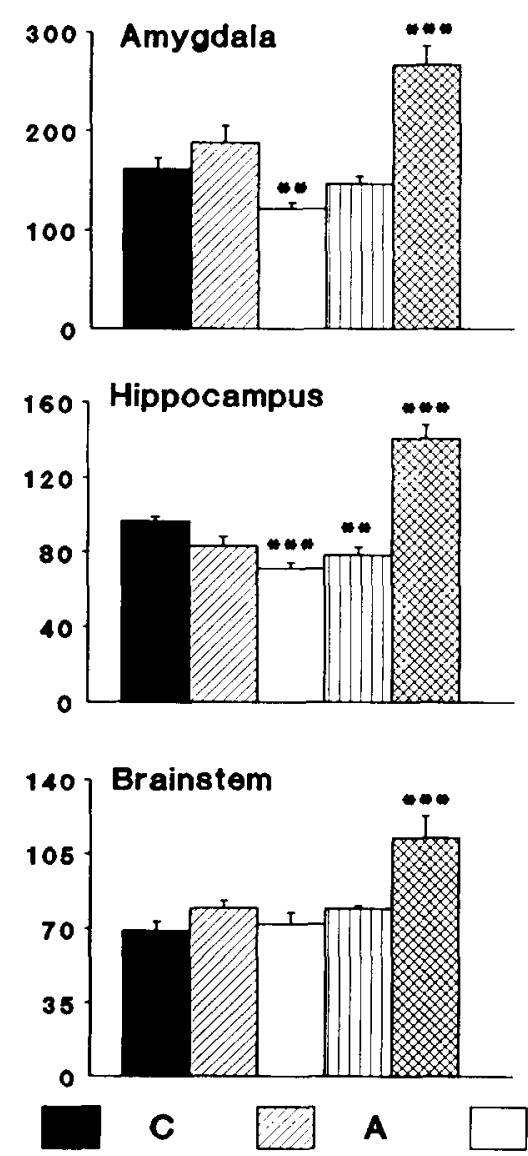

the rat brain was uneven and similar to that reported previously (Smith et al., 1981; fig. 1). The highest degree of binding (in $\mathrm{fmol} / \mathrm{mg}$ protein) occurred with membranes isolated from the amygdala $(162 \pm 12, \mathrm{n}=12)$, hypothalamus (147 $\pm 7, \mathrm{n}=13)$ and parietal-occipital cortex $(138 \pm 6$, $\mathrm{n}=12)$; intermediate values were obtained with membranes from the hippocampus $(97 \pm 3, \mathrm{n}=$ 12); and the lowest values with membranes from the brainstem $(69 \pm 5, \mathrm{n}=11)$ and caudate nucleus $(62 \pm 3, n=10)$. Analysis with the Munson and Rodbard (1981) program, LIGAND, indicated that the data fitted best a model based on a single population of binding sites. $\mathrm{K}_{\mathrm{D}} \mathrm{s}$ ranged from $2.7 \pm 0.3 \mathrm{nM}(\mathrm{n}=10)$ for binding to membranes
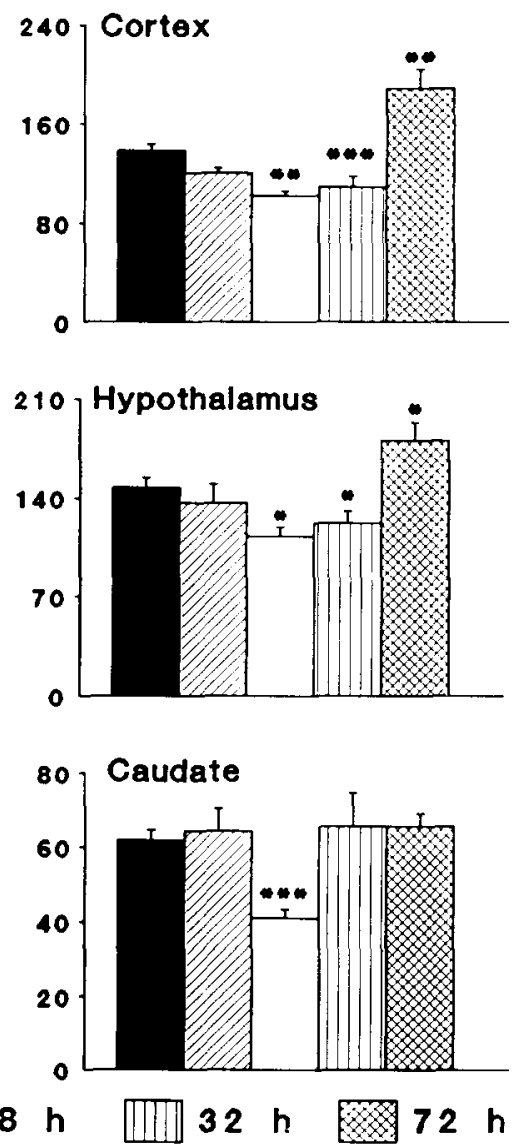

Fig. 1. Binding of $\left[{ }^{3} \mathrm{H}\right]$ clonidine to neural membranes isolated from various areas of the rat brain. Rats were treated with saline (C) or with increasing doses of morphine as described in Methods. The maximum number of binding sites $\left(B_{\max }\right)$ were measured at 8,32 or $72 \mathrm{~h}$ after the last injection of morphine. In some experiments (A) rats were treated with morphine, $10 \mathrm{mg} / \mathrm{kg}$ per injection, every $8 \mathrm{~h}$ for 1 day and killed $8 \mathrm{~h}$ after the last injection. Each value represents the mean of 3-8 determinations. Vertical bars represent the S.E.M. ${ }^{*} \mathrm{P}<0.05,{ }^{*} * \mathrm{P}<0.005,{ }^{*} * \mathrm{P}<0.0005$. Ordinate: $\mathrm{B}_{\max }(\mathrm{fmol} / \mathrm{mg}$ protein). 
from caudate nucleus to $4.5 \pm 0.9 \mathrm{nM}(\mathrm{n}=13)$ for membranes from the hypothalamus. None of the treatments caused statistically significant changes in $\mathrm{K}_{\mathrm{D}} \mathrm{s}$ for binding of $\left[{ }^{3} \mathrm{H}\right]$ clonidine to membranes isolated from any brain area.

When measured $8 \mathrm{~h}$ after the last injection of morphine, the specific binding of $\left[{ }^{3} \mathrm{H}\right]$ clonidine to - neural membranes isolated from rats treated for 14 days was significantly decreased (fig. 1). At this time the rats were highly dependent and signs of the morphine-abstinence syndrome had not yet developed. When compared to controls treated for 14 days with saline, the following decreases in binding were observed: amygdala $(-25 \pm 4 \%, \mathrm{n}=$ $6, P<0.005)$, parietal-occipital cortex $(-26 \pm 3 \%$, $\mathrm{n}=8, \mathrm{P}<0.005)$, hypothalamus $(-23 \pm 4 \%, \mathrm{n}=$ $6, \mathrm{P}<0.05)$, hippocampus $(-26 \pm 3 \%, \mathrm{n}=7, \mathrm{P}<$ $0.0005)$ and caudate nucleus $(-34 \pm 4 \%, \mathrm{n}=3$, $\mathrm{P}<0.005)$. In contrast, specific binding of $\left[{ }^{3} \mathrm{H}\right]$ clonidine to neural membranes from the brainstem was slightly but not significantly increased $(+3 \%, \mathrm{n}=6)$.

Although still depressed at $32 \mathrm{~h}$ after the last morphine injection, the specific binding of $\left[{ }^{3} \mathrm{H}\right]$ clonidine started to return toward normal values for membranes isolated from the cortex, hippocampus, hypothalamus and amygdala (fig. 1). At this time all dependent animals demonstrated a full abstinence syndrome and experienced a marked weight loss (mean loss $28.3 \pm 0.4 \%, \mathrm{n}=$ 30 ). When compared to saline-treated controls the following decreases were observed: parietal-occipital cortex $(-21 \pm 6 \%, \mathrm{n}=5, \mathrm{P}<0.05)$, hippocampus $(-19 \pm 5 \%, \mathrm{n}=5, \mathrm{P}<0.005)$ and hypothalamus $(-17 \pm 6 \%, \mathrm{n}=3, \mathrm{P}<0.05)$. Specific binding of $\left[{ }^{3} \mathrm{H}\right]$ clonidine was not significantly different from control values for the amygdala $(-9$ $\pm 5 \%, \mathrm{n}=3)$, caudate nucleus $(+6 \pm 15 \%, \mathrm{n}=3)$ and brainstem $(+29 \pm 2 \%, \mathrm{n}=3)$.

Seventy-two hours after the last morphine injection marked increases occurred in the specific binding of $\left[{ }^{3} \mathrm{H}\right]$ clonidine to membranes isolated from the amygdala, parietal-occipital cortex, hippocampus, hypothalamus and brainstem of morphine-treated rats (fig. 1). When compared to saline-treated controls, the following increases occurred: amygdala $(+66 \pm 12 \%, \mathrm{n}=6, \mathrm{P}<0.005)$, parietal-occipital cortex $(+37 \pm 11 \%, \mathrm{n}=5, \mathrm{P}<$
$0.005)$, hippocampus $(+46 \pm 8 \%, \quad \mathrm{n}=6, \quad \mathrm{P}<$ $0.005)$, hypothalamus $(+23 \pm 9 \%, \mathrm{n}=6, \mathrm{P}<0.05)$, and brainstem $(+64 \pm 15 \%, \mathrm{n}=5, \mathrm{P}<0.0005)$. Only binding to caudate membranes remained unchanged $(+6 \pm 6 \%, n=4)$.

Short-term treatment of rats with morphine, 10 $\mathrm{mg} / \mathrm{kg}$ t.i.d. for 1 day, did not alter the specific binding of $\left[{ }^{3} \mathrm{H}\right]$ clonidine to membranes from any brain area. After a single day of morphine administration the $B_{\max } \mathrm{s}\left(\mathrm{fmol} / \mathrm{mg}\right.$ protein) and $\mathrm{K}_{\mathrm{D}} \mathrm{S}$ $(\mathrm{nM})$ were as follows: amydala $(188 \pm 17,2.5 \pm$ $0.31, \mathrm{n}=4)$, parietal-occipital cortex $(121 \pm 4,2.5$ $\pm 0.5, \mathrm{n}=3)$, hippocampus $(84 \pm 5,3.3 \pm 0.4)$, hypothalamus $(136 \pm 14,4.0 \pm 0.8, \mathrm{n}=5)$, brainstem $(80 \pm 4,2.4 \pm 0.3, n=4)$ and caudate nucleus (64 $\pm 6,3.0 \pm 0.5, n=4)$. Furthermore, in equilibrium experiments, morphine, when added in vitro in concentrations up to and including $100 \mu \mathrm{M}$, failed to displace $\left[{ }^{3} \mathrm{H}\right]$ clonidine from membranes isolated from the hippocampus or from the parietaloccipital cortex.

\subsection{Field stimulation of rat hippocampal slices}

When rat hippocampal slices from saline-treated controls, prelabelled with $\left[{ }^{3} \mathrm{H}\right]$ noradrenaline, were stimulated at $1 \mathrm{~Hz}\left(\mathrm{~S}_{1}\right)$ for $2 \mathrm{~min}, 0.48 \pm 0.06 \%$ of the labelled amine was released in excess of the spontaneous efflux of tritium (table 1). Preliminary experiments in which $\left[{ }^{3} \mathrm{H}\right]$ noradrenaline was separated from its metabolites on Dowex columns indicated that greater than $90 \%$ of the released tritium represented unmetabolized $\left[{ }^{3} \mathrm{H}\right]$ noradrenaline. When stimulated at a frequency of $4 \mathrm{~Hz}\left(\mathrm{~S}_{2}\right)$, the fractional release was $1.21 \pm 0.15 \%(n=11)$ and the $S_{2} / S_{1}$ ratio was $2.58 \pm 0.10$ (table 1 ).

When measured $8 \mathrm{~h}$ after the last injection of morphine, the fractional release during both $\mathrm{S}_{1}$ $(+62.5 \%, \mathrm{n}=6, \mathrm{P}<0.02)$ and $\mathrm{S}_{2}(+29.8 \%, \mathrm{n}=6)$ was increased although the increase during $S_{2}$ did not reach statistical significance. The $S_{2} / S_{1}$ ratio was significantly decreased $(-19 \%, n=6, P<$ 0.02 ) which indicated a greater increase in release at the lower frequency of stimulation than at the higher. The fractional release of $\left[{ }^{3} \mathrm{H}\right]$ noradrenaline was increased further during both $\mathrm{S}_{1}(+87.5 \%$, $\mathrm{n}=4, \mathrm{P}<0.002)$ and $\mathrm{S}_{2}(+60.3 \%, \mathrm{n}=4, \mathrm{P}<0.01)$ 
$32 \mathrm{~h}$ after the last injection of morphine, and the $\mathrm{S}_{2} / \mathrm{S}_{1}$ ratio was still decreased $(-16.7 \%, \mathrm{P}<0.02)$. The fractional release of $\left[{ }^{3} \mathrm{H}\right]$ noradrenaline remained increased during both $\mathrm{S}_{1}(+81.3 \%, \mathrm{n}=5$, $\mathrm{P}<0.001)$ and $\mathrm{S}_{2}(+55.4 \%, \mathrm{n}=5, \mathrm{P}<0.01)$, and the $\mathrm{S}_{2} / \mathrm{S}_{1}$ ratio remained depressed $(-15.9 \%, \mathrm{P}<$ $0.02)$ at $72 \mathrm{~h}$ after the last injection of morphine. These results are consistent with a subsensitivity of the $\alpha_{2}$-adrenoceptor at all three time intervals after the last administration of morphine to dependent rats.

\subsection{Clonidine concentration-effect curves}

Further evidence for a subsensitivity of $\alpha_{2-}$ adrenoceptors after chronic morphine administration was manifested by changes in the response of the hippocampal slices to clonidine. The $\mathrm{EC}_{50}$ for inhibition by clonidine of $\left[{ }^{3} \mathrm{H}\right]$ noradrenaline release from hippocampal slices from saline-treated rats was $4.7 \pm 0.6 \mathrm{nM}(\mathrm{n}=11$, table 1$)$. The value was similar to the $K_{D}$ for $\left[{ }^{3} \mathrm{H}\right]$ clonidine binding to neural membranes from the normal rat hippocampus $(3.7 \pm 0.5 \mathrm{nM}, \mathrm{n}=12)$. Eight hours after the last injection of morphine to dependent rats, there was a 10 -fold shift to the right in the cloni-

\section{TABLE 1}

Fractional release of $\left[{ }^{3} \mathrm{H}\right]$ norepinephrine during field stimulation of hippocampal slices from control and morphine-treated rats. Sensitivity to clonidine. Fractional release of $\left[{ }^{3} \mathrm{H}\right]$ norepinephrine at $1 \mathrm{~Hz}\left(\mathrm{~S}_{1}\right)$ or $4 \mathrm{~Hz}\left(\mathrm{~S}_{2}\right)$ is expressed as a percent of the total $\left[{ }^{3} \mathrm{H}\right]$ norepinephrine in the tissue at the onset of the period of stimulation. Rats were treated for 14 days with increasing doses of morphine as described in Methods. Each value represents the mean of 4-11 determinations \pm S.E.M.

\begin{tabular}{|c|c|c|c|c|}
\hline Condition & $\begin{array}{l}S_{1} \\
(1 \mathrm{~Hz})\end{array}$ & $\begin{array}{l}S_{2} \\
(4 \mathrm{~Hz})\end{array}$ & $\begin{array}{l}S_{2} / S_{1} \\
\text { Ratio }\end{array}$ & $\begin{array}{l}\text { Clonidine } \\
\mathrm{EC}_{50}(\mathrm{nM})\end{array}$ \\
\hline \multirow[t]{2}{*}{ Control } & 0.48 & 1.21 & 2.58 & 4.7 \\
\hline & \pm 0.06 & \pm 0.15 & \pm 0.10 & \pm 0.6 \\
\hline \multicolumn{5}{|l|}{ Withdrawn } \\
\hline \multirow[t]{2}{*}{$8 \mathrm{~h}$} & $0.78^{a}$ & 1.57 & $2.09^{\mathrm{a}}$ & $47.2^{\mathrm{a}}$ \\
\hline & \pm 0.14 & \pm 0.16 & \pm 0.19 & \pm 5.3 \\
\hline \multirow[t]{2}{*}{$32 \mathrm{~h}$} & $0.90^{\mathrm{d}}$ & $1.94^{b}$ & $2.15^{a}$ & $9.2^{\mathrm{b}}$ \\
\hline & \pm 0.09 & \pm 0.21 & \pm 0.06 & \pm 1.9 \\
\hline \multirow[t]{2}{*}{$72 \mathrm{~h}$} & $0.87^{c}$ & $1.88^{b}$ & $2.17^{\mathrm{a}}$ & $12.9^{\circ}$ \\
\hline & \pm 0.06 & \pm 0.10 & \pm 0.09 & \pm 3.5 \\
\hline
\end{tabular}

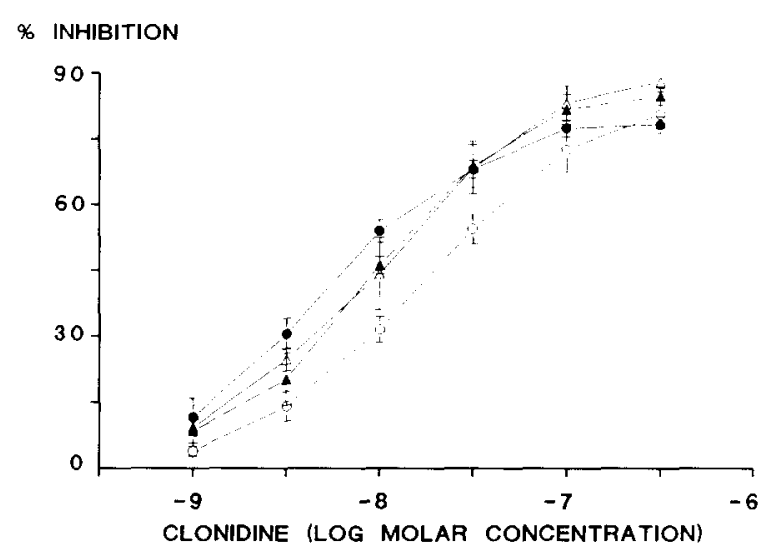

Fig. 2. Inhibition of the release of $\left[{ }^{3} \mathrm{H}\right.$ noradrenaline by clonidine during field stimulation of hippocampal slices from saline or morphine-treated rats. Abscissa, molar concentration of clonidine in perfusate. Ordinate, fractional release of $\left[{ }^{3} \mathrm{H}\right]$ noradrenaline expressed as a percent of release prior to administration of clonidine. Rats were treated for 14 days with increasing doses of morphine as described in Methods. Determinations were made on hippocampal slices from 11 saline control rats (solid circles), and at $8 \mathrm{~h}$ (open circles, $\mathbf{n}=7$ ), $32 \mathrm{~h}$ (solid triangles, $n=4$ ) and $72 \mathrm{~h}$ (open triangles, $n=4$ ) after the last injection of morphine. Each point represents the mean value. Vertical bars represent the S.E.M.

dine concentration effect curve (fig. 2) as indicated by a significant increase in the $\mathrm{EC}_{50}$ for clonidine $(47.2 \pm 5.3, \mathbf{n}=6, \mathrm{P}<0.02$, table 1$)$. At both 32 and $72 \mathrm{~h}$ after the last morphine injection, the clonidine concentration-effect curves remained shifted to the right (fig. 2, table 1), although to a lesser extent than observed at $8 \mathrm{~h}$. At none of the time intervals were the maximum responses to clonidine significantly altered.

\section{Discussion}

The binding of $\left[{ }^{3} \mathrm{H}\right]$ clonidine to neural membranes isolated from the rat brain has been used extensively to evaluate the status of $\alpha_{2}$-adrenoceptors in animals treated chronically with morphine. The present study demonstrates significant decreases in the density of $\alpha_{2}$-adrenoceptors on neural membranes isolated from the amygdala, occipital-parietal cortex, hippocampus, hypothalamus and caudate nucleus 8 and $32 \mathrm{~h}$ after the last injection of morphine to dependent rats and large 
increases in the density of $\alpha_{2}$-adrenoceptors $72 \mathrm{~h}$ after the last morphine injection. Previous studies of changes in $\left[{ }^{3} \mathrm{H}\right]$ clonidine binding to rat neural membranes after 'chronic' morphine treatment have reported highly divergent results. Hamburg and Tallman (1980) found that implantation of rats with $75 \mathrm{mg}$ morphine pellets for 3 days resulted in increased binding of $\left[{ }^{3} \mathrm{H}\right]$ clonidine to membranes isolated from cerebral cortex and brainstem. Smith et al. (1983) found decreases in the specific binding of $\left[{ }^{3} \mathrm{H}\right]$ clonidine to neural membranes from various brain areas isolated from rats injected with increasing doses of morphine for 14 days. With a treatment protocol similar to that of Hamburg and Tallman (1980), Vincentini et al. (1983) found to change in the binding of $\left[{ }^{3} \mathrm{H}\right]$ clonidine to rat cortical membranes. Sethy and Harris (1982) also found no change in the binding of $\left[{ }^{3} \mathrm{H}\right]$ clonidine to neural membranes when rats were infused i.v. with morphine over a period of 10 days. When rats were given increasing concentrations of morphine in their drinking water for various periods of time, Ulibarri et al. (1987) found increases, decreases or no changes in the binding of $\left[{ }^{3} \mathrm{H}\right]$ clonidine to neural membranes from various brain areas. Factors which might underlie these differences include the dose and dosage form of the morphine which was administered, the frequency of morphine administration and the area of the brain which was studied. Such factors previously have been shown to be extremely important in determining the direction of change in $\alpha_{2}$-adrenoceptor density after the administration of tricyclic antidepressants (Smith and Hollingsworth, 1983; 1984).

Recently changes in the density of cortical and hippocampal $\beta$-adrenoceptors were found to be well-correlated with changes in the sensitivity of cortical and hippocampal neurons to $\beta$-adrenergic stimulation at various intervals of time after the last injection of morphine to rats treated chronically according to a schedule which was the same as that used in the present study (Moises and Smith, 1984; 1987; in press). However, the functional significance of changes in $\alpha_{2}$-adrenoceptor density after chronic morphine administration has not been elucidated previously. Most electrophysiological studies of $\alpha_{2}$-adrenoceptor function after chronic morphine administration have been performed upon cells located in the rat locus coeruleus. In these studies schedules of morphine administration which result in tolerance to opiates failed to modify cellular responses to $\alpha_{2}$-adrenoceptor agonists such as clonidine (Aghajanian, 1978; Andrade et al., 1983; Christie et al., 1987). Such observations are consistent with the present study in which no changes in $\alpha_{2}$-adrenoceptor density were found with neural membranes isolated from the region of the brainstem which contains the locus coeruleus at either 8 or $32 \mathrm{~h}$ after the last injection of morphine to chronically treated animals.

In the present study a good correlation was found between changes in $\alpha_{2}$-adrenoceptor density in the hippocampus and changes in the sensitivity of presynaptic $\alpha_{2}$-adrenoceptors to clonidine during field stimulation of hippocampal slices when studied at either 8 or $32 \mathrm{~h}$ after the last injection of morphine to rats treated for 14 days. The decrease in $\alpha_{2}$-adrenoceptor sensitivity was associated with an increase in the fractional release of $\left[{ }^{3} \mathrm{H}\right]$ noradrenaline during field stimulation, especially at the lower frequency $(1 \mathrm{~Hz})$ of stimulation. This receptor subsensitivity could account for increased release of noradrenaline which has been associated with the opiate withdrawal syndrome (Swann et al., 1983; Charney et al., 1984).

In contrast to the earlier time intervals, at $72 \mathrm{~h}$ after the last injection of morphine to the dependent rats, a marked increase in $\alpha_{2}$-adrenoceptor number was found with membranes isolated from all brain areas except the caudate nucleus. Ulibarri et al. (1987) reported similar increases in $\alpha_{2}$ adrenoceptor density in rat hypothalamus, cerebral cortex and brainstem during withdrawal. However, in the present study, these increases in $\alpha_{2}-$ adrenoceptor density in the hippocampus were not accompanied by a similar increase in presynaptic receptor sensitivity to clonidine. These findings do not support the suggestion that there exists a supersensitivity of $\alpha_{2}$-adrenoceptors in the brains of dependent subjects during withdrawal (GarciaSevilla et al., $1985 ; 1987)$. In fact, $\alpha_{2}$-adrenoceptors remained subsensitive to clonidine at $72 \mathrm{~h}$ after the last injection, a time when all signs of withdrawal had subsided completely. Thus, this 
study shows that the changes in the size of the total population of $\alpha_{2}$-adrenoceptors on neural membranes isolated from the brain are not necessarily correlated with changes in the function of presynaptic $\alpha_{2}$-adrenoceptors.

Since a large proportion of $\alpha_{2}$-adrenoceptor binding sites in the rat brain are postsynaptic rather than presynaptic (Smith and Hollingsworth, 1983; U'Prichard, 1984), it is possible that the increase in $\alpha_{2}$-adrenoceptor density seen at $72 \mathrm{~h}$ after the last morphine injection to dependent rats represents an increase in postjunctional $\alpha_{2}$-adrenoceptors. An alternative explanation of the increase in $\alpha_{2}$-adrenoceptor density combined with a decrease in receptor function is that although the number of receptors is increased, fewer receptors are coupled so that receptor occupation results in a diminished inhibition of $\left[{ }^{3} \mathrm{H}\right]$ noradrenaline release. The basis and significance of these changes in receptor density and function remain to be elucidated.

\section{Acknowledgements}

Supported by U.S. Public Health Service Grants DA-03365 and MH-36226.

\section{References}

Aghajanian, G.K., 1978, Tolerance of locus coeruleus neurons to morphine and suppression of withdrawal response by clonidine, Nature 276, 186.

Andrade, R.A., C.P. VanderMailen and G.K. Aghajanian, 1983, Morphine tolerance and dependence in the locus coeruleus: single cell studies in brain slices, European J. Pharmacol. $91,161$.

Bylund, D.B. and D.C. U'Prichard, 1983, Characterization of alpha $_{1^{-}}$and alpha ${ }_{2}$-adrenoceptors, Int. Rev. Neurobiol. 24, 343.

Charney, D.S., D.E. Redmond, Jr., M.D. Galloway, H.D. Kleber, G.R. Heninger, M. Murberg and R.H. Roth, 1984, Naltrexone precipitated opiate withdrawal in methadone addicted human subjects: evidence for noradrenergic hyperactivity, Life Sci. 35, 1263.

Christie, M.J., J.T. Williams and R.A. North, 1987, Cellular mechanisms of opioid tolerance: studies in single brain neurons, Mol. Pharmacol. 32, 633.

Clouet, D.H. and M. Ratner, 1970, Catecholamine biosynthesis in brains of rats treated with morphine, Science 168, 854.
Garcia-Sevilla, J.A., L. Ugedo, I. Ulibarri and M. Gutierrez, 1985, Platelet $\alpha_{2}$-adrenoceptors in heroin addicts during withdrawal and after treatment with clonidine, European $\mathbf{J}$. Pharmacol. 114, 365.

Garcia-Sevilla, J.A., I. Ulibarri, L. Ugedo and M. Gutierrez, $1987, \alpha_{2}$-Adrenoceptor-mediated inhibition of platelet adenylate cyclase activity in heroin addicts in abstinence, Psychopharmacology 92, 320.

Glowinski, J. and L.L. Iversen, 1966, Regional studies of catecholamines in the rat brain. I. The disposition of ${ }^{3} \mathrm{H}-$ norepinephrine, ${ }^{3} \mathrm{H}$-dopamine and ${ }^{3} \mathrm{H}$-dopa in various regions of the brain, J. Neurochem. 13, 655 .

Goldstein, A., 1964, Biostatistics (The McMillan Co., N.Y.).

Hamburg, M. and J.F. Tallman, 1981, Chronic morphine administration increases the apparent number of $\alpha_{2}$-adrenergic receptors in rat brain, Nature (London) 291, 493.

Langer, S.Z., 1981, Presynaptic regulation of the release of catecholamines, Pharmacol. Rev. 32, 337.

Lowry, O.H., N.F. Rosebrough, A.G. Farr and R.J. Randall, 1951, Protein measurement with the Folin phenol reagent, J. Biol. Chem. 193, 265.

McPherson, G.S., 1983, A practical computer-based approach to the analysis of radioligand binding experiments, Comput. Prog. Biomed. 17, 107.

Moises, H.C. and C.B. Smith, 1984, Changes in central adrenoceptor function occur after long-term opiate treatment, Neuropeptides 5, 29.

Moises, H.C. and C.B. Smith, 1987, Changes in cortical beta adrenergic receptor density and neuronal sensitivity to norepinephrine accompany morphine dependence and withdrawal, Brain Res. 400, 110.

Moises, H.C. and C.B. Smith, Electrophysiological responsiveness to isoproterenol in rat hippocampal slices correlates with changes in $\beta$-adrenergic receptor density induced by chronic morphine treatment, Brain Res. (in press).

Moises, H.C., C.B. Smith, R.N. Spengler and P.J. Hollingsworth, 1986, Presynaptic alpha ${ }_{2}$ adrenoceptor function in dependent rats before and after morphine withdrawal, in: Progress in Opioid Research, NIDA Research Monograph 75, eds. J.W. Holaday et al. (U.S. Government Printing Office, Washington) p. 579.

Munson, P.J. and D. Rodbard, 1980, LIGAND: a versatile computerized approach for characterization of ligand-binding systems, Anal. Biochem. 107, 220.

Rosenman, S.J. and C.B. Smith, 1972, ${ }^{14}$ C-Catecholamine synthesis in mouse brain during morphine withdrawal, $\mathrm{Na}$ ture (London) 240, 153.

Sethy, V.H. and D.W. Harris, 1982, Effect of chronic morphine treatment on $\alpha_{2}$-adrenergic receptors in rat brain and spinal cord, Res. Commun. Subst. Abuse 3, 121.

Smith, C.B., J.A. Garcia-Sevilla and P.J. Hollingsworth, 1981, Alpha ${ }_{2}$-adrenoreceptors in rat brain are decreased after long-term tricyclic antidepressant drug treatment, Brain Res. 210, 413.

Smith, C.B. and P.J. Hollingsworth, 1983, Alpha ${ }_{2}$-adrenoreceptors and the mechanism of action of tricyclic antidepressant drugs, in: Neuronal and Extraneuronal Events in Auto- 
nomic Pharmacology, eds. W.W. Fleming et al. (Raven Press, New York) p. 181.

Smith, C.B. and P.J. Hollingsworth, 1984, Alpha ${ }_{2}$-adrenoreceptors and antidepressant treatments, in: Proceedings, IUPHAR 9th International Congress of Pharmacology, London, Vol. 3, eds. W. Paton et al. (The MacMillan Press, Ltd., London) p. 131.

Smith, C.B., P.J. Hollingsworth, J.J. Geer and H.C. Moises, 1983, Changes in alpha ${ }_{2}$ adrenoreceptors in various areas of the rat brain after long-term administration of 'mu' and 'kappa' opiate agonists, Life Sci. 33 (Suppl. I), 369.

Smith, C.B., M.J. Sheldon, J.H. Bednarczyk and J.E. Villarreal, 1972, Morphine-induced increases in the incorporation of ${ }^{14} \mathrm{C}$-tyrosine to ${ }^{14} \mathrm{C}$-dopamine and ${ }^{14} \mathrm{C}$-norepinephrine in the mouse brain, J. Pharmacol. Exp. Ther. 180, 547.

Smith, C.B., J.E. Villarreal, J.H. Bednarczyk and M.I. Sheldon, 1970, Tolerance to morphine-induced increases in $\left[{ }^{14} \mathrm{C}\right]$ catecholamine synthesis in mouse brain, Science 170 , 1106.
Starke, K., 1981, Presynaptic receptors, Ann. Rev. Pharmacol. Toxicol. 21, 7 .

Swann, A.C., J.D. Elsworth, D.S. Charney, D.M. Jablons, R.H. Roth, D.E. Redmond, Jr. and J.W. Mass, 1983, Brain catecholamine metabolites and behavior in morphine withdrawal, European J. Pharmacol. 86, 167.

Ulibarri, I., J.A. Garcia-Sevilla and L. Ugedo, 1987, Modulation of brain $\alpha_{2}$-adrenoceptor and $\mu$-opioid receptor densities during morphine dependence and spontaneous withdrawal in rats, Naunyn-Schmiedeb. Arch. Pharmacol. 336,530 .

U'Prichard, D.C., 1984, Biochemical characteristics and regulation of brain alpha ${ }_{2}$-adrenoceptors, Ann. N.Y. Acad. Sci. $430,55$.

Vicentini, L.M., R.J. Miller and M.J. Robertson, 1983, Chronic opiate treatment does not modify $\alpha_{2}$-adrenergic receptors in rat cerebral cortex, kidney and in the neurotumor cell line NCB20, European J. Pharmacol. 95, 265. 